\title{
The subjectivity of older adults in the late works of eminent creators
}

\begin{abstract}
This article shows - in the light of personalistic psychology - the subjective features of old people which are manifested in the works of eminent creators. The progress of inner subjectivity is shown as a specific developmental tendency. It is characterized by reflection, concentration on one's own experiences, remembrances and encapsulating life events. It is readily observable that old creators are open to spiritual values and that melancholy is a predominant mood in their creation.
\end{abstract}

Key words: inner subjectivity, elderly, creative activity, life balance, openness to spiritual values

\section{Introduction}

For humans, being a subject is not only an objective fact or mode of existence characterized by intentional activity and agency as is the case with entities of other kinds (e.g. institutional, legal, political one etc.) but above all it is an ontological as well as existential fact related to personal condition and at the same time a merit and obligation/life task. This means that human being as a personal being is naturally endowed with specific attributes typical of the homo sapiens species, predisposing one towards one's particular kind of activity. These attributes, as differentia specifica of a human being, constitute the potential in a somewhat seed form to be derived from throughout life - also in its latter part and even into the old age. Due to the subject endowment, in other words the innate subjectivity potential, which offers possibilities of being a subject all the time and everywhere, regardless of any circumstances, unconditional dignity decidedly appertains to man. It is the dignity no one can take away from you; this dignity is neither earned nor conferred by any instance whatsoever but it stems from the sheer fact of its humanity - borne quality being simply a person or personal subject.

\section{The attributes of a personal subject}

A human being, as a personal being is a cognitiveopen (ex-centric) being. This means not only is he capable of intravital transcendence of material, sensually observable reality and contemplativeness predicated upon knowledge and rational, logical reasoning but also upon experiences, encompassing the entirety of experience entailing feelings and intuition. Cognitive openness prepossesses human beings in favor of continually taking interest in the world, fathoming its mysteries, learning oneself, finding out about one's identity the effect of which is self-awareness as well as its peculiar form, to wit the reflective awareness. The tendency to experiencing uncertainty and posing questions which are difficult to answer in an unambiguous and clear-cut manner - while staying in tune with rationality based on cause-and-effect logic - exemplifies this sort of contemplativeness. Being a reflective being a man is capable of looking at the world from different points of view, marveling at its mysteries and seeking superordinate as opposed to pro tempore or pragmatic meaning of occurrences, he explores rationale, reasons for why events happen as distinct from their mere direct, definite causes and after-effects. In search for the answers to these questions, which go beyond model-based reality, one has to provide for extensive background of meaning as well as a long-range perspective such as historical, biographical, and even eschatological one. Essentially, specific, postformal thinking processes such as contextual, paradoxical and dialectical thought (Trempała, 2011), along with intuition, imagination thanks to which the engaging all of the cognitive dispositions a human mind is endowed with makes the aforementioned existant condition possible to take place in an adult. The life of a man-the-subject subjected to contemplativeness,

\footnotetext{
Institute of Psychology, Wroclaw University 
conscious meaning-oriented construal of events does not solely pivot around survival and adaptation or acquiring manifold advantages over others and the ensuing satisfaction or pleasure as a result. Rather, such life is being thoroughly lived - which means it surpasses mere existence itself. Among the most existentially significant experiences are those whose contents concern facing evanescence, ruthless irreversibility of events along with the inevitability of the end of life (Gadamer, 2003). Those experiences are usually accompanied by the fear of nonexistence, emptiness and the final futility of all temporal struggles (Tillich, 1983). Since everything goes by which, eventually, amounts to vanity - so what is the point of all our strivings, endeavors, random and unacceptable events, especially the painful ones which are hard to bear and simply critical such as nonculpable suffering. The key existential questions a thoughtfully-disposed person asks themselves or the world are the identity type questions such as: Who am I? What am I for? Where am I coming from? Where am I going to? Where do I place myself in this world? What is my life journey supposed to be like? These kind of questions posed by man at different stages of his development direct his insight into higher values and meaning of life in general. Such queries start appearing and require answering especially at turning points such as entering puberty, adulthood, or going beyond the midlife threshold - they all constitute the axis of developmental crisis. The resultant answers are instrumental in making vital life-choices relating to, among others, worldview, profession or civil status. Predicated upon them are formulated life-goals the achievements of which plays an important role in the overall sense of meaning of life together with the subjective evaluation of its quality. A man in his youth and early adolescence makes attempts at fulfilling his need for meaning by way of creating and achieving particular goals, thereby understanding meaning to be part of the future perspective (in spe), whereas at later stages of life, especially late adulthood, when the possibilities of accomplishing goals have considerably diminished and -additionally outlook on the future gets naturally narrowed down, meaning of life is chiefly sought in the past (ex post), things which are now gone, yet have left lasting traces in the form of recurring memories, e.g. biographical memory. The expression of the need for experiencing the meaning of passing life is known to developmental psychologist as the "return to the past" phenomenon in elder people as well as accomplishing the final developmental task which is referred to as balance sheet of life (Erikson, 2004; Straś-Romanowska, 2011). It is the life outcome that the spirits of the elderly depend on, whether they will be characterized by - in its excessive manifestation - mental integration, harmony and peace of mind, or lack of reconciliation with oneself and the world, leaving one filled with grief and despair.

The cognitive openness of the man-the-subject refers to the world of absolute/spiritual values which is exhibited by the sensitivity to the good and seeking superordinate, ultimate truth. Not only is a man motivated by the yearning for truth to discover laws governing life (the natural, social, psychological ones) but it also prompts him to search for the Law Maker, that is a source higher than made-made laws, in other words, the Maker Himself. Hence springs the perennial human need for the religious cult and faith in God as a an omnipotent wisdom and agency. According to anthropologists, from among living beings, it is only man who feels the need for faith in Higher Power and practicing religious rituals. British biologist Alister Hardy even describes the homo sapiens species as "praying animal" (Schnabel, 2015; see: Prusak, 2016). Along similar lines, thanks to the aesthetic need hardwired for sensitivity to beauty, a man as an exponent of a unique species has come to be the creator of culture (Vetulani, 2011). Another distinctive feature of man-the-subject, who is open to higher values - what is worth noting - is the ability to tell right from wrong and the need/will to follow the good. Although the will of conduct is not always in line with moral imperative or acceptable values at that, this however does not alter the fact that the will does exist which is, for instance, denoted by lived experiences such as sense of guilt, shame, repentance or regret.

One of the most frequently displayed attributes of human subjectivity in social discourse and also psychological dissertations is the intentional activeness whose origins are found in the need for agency and creativity, the specific nature of which is given/provided by the free will. Thanks to cognitive openness and on the man's basis of the need for creativity, human behavior is not exclusively restricted to reactive, passive adaptation to the demands of the outside world. Rather, it primarily depends on the innovative activeness geared towards changing environmental conditions according to one's own ideas, ideals and intents, proactively. Although all activeness brings some developmental changes, there does exist a peculiar way of activity which is characterized by intentional targeting towards (self) development. This activity is purposefully pro-development as a target, stemming from personal will/intention of changing life position/situation, exceeding one's limitations, overcoming one's weaknesses or pursuing self-development. The axiological intention is a significant element in engaging free will to the greatest possible extent. The prerequisite for taking action in this case, apart from the awareness of the aim in mind, is also the reflection on various consequences of conduct related to which is responsibility. By extension, intentionality acquires moral nature - it ceases to merely be a possibility, the exercise of freedom and it additionally starts to become some sort of obligation. (Kant, 2001; Straś-Romanowska, 2010; Trzópek, 2013). Human action is preceded then by an act of choice, based on moral judgment by virtue of superordinate values as opposed to the pragmatic, utilitarian, or hedonistic ones alone. The experience of both moral commitment and responsibility for (non) action constitute a specific prioritized component of human subjectivism. Sense of responsibility towards values or because of values espoused by a given individual makes him - at the same time and eventually - responsible relative to himself and for himself to boot. 


\section{The subjectivity of an eldery person}

In youth and into early adolescence intentional activeness considerably takes the form of realized transgression by virtue of social standards, image, it is also used for getting approval, boosting self-esteem and attaining desirable status. Although the personal potential as a criterion and essential characteristic is a constant, with age the tapping into it undergoes changes on a person's dayto-day functioning. Thus, there are different developmental tasks for children, youngsters and adults as well as the retired individuals. Moreover, people at different stages of their physical and mental development have other capabilities available. It may be generally considered that outer intentionality directed at gaining knowledge about the world and oneself, redeveloping reality that surrounds one, the co-creation of one's identity or self-image building via developing various advantages, perfecting one's resources and their actualization, which is self-actualization at that -gradually gives way to inner intentionality. Its essence lies in focusing on one's own experiences, the previously acquired overall experience as such, the symbolic reality present in the mind becomes the focus of attention, then more than the physical, real world does; it emerges that the meaning of facts becomes much more important than the content or their relating knowledge. In other words, with man's development, there usually increases reflective mood, the need for addressing and interpretation of events. Also, a human being comes to a wider understanding of occurrences in the light of their specific values as well as the context of passing, which is equivalent with searching for the profound meaning of events and one's own life as the most important, holistic event for any individual. Inner intentionality is not only, stricte psychologically based in the form of accumulated abundance of experiences gained in the course of life, but most of all, it is conditioned biologically. As neurobiologists argue, the functions of the right brain wane with age. However, the left brain stays viable for longer, becoming dominant over time (Goldberg, 2011; Vetulani, 2013). Together with this process there decrease, among other things, the efficiency of working memory, new information absorption, spatial orientation along with temporal perspective and prospective thinking - decision-making and courage grow weaker as well. At the same time, verbal efficiency, semantic and reminiscent memory remain intact. Along with these processes appears the tendency to retrospective thinking to boot. The concentration on nearby places, on things which are known and already familiar to the elder people also begins to prevail over former inclinations. These functional changes in the brain of an elderly person are additionally accompanied by transformations made in the sphere of mental processes. Beside the logical, cause-and-effect thinking - remaining at a relatively constant level - what proves to be efficient is the postformal, contextual and dialectical processes. The aforementioned processes are beneficial to bringing order to the experiences not only by way of linear principle - according to the frequency and chronological criterion but also on the relation basis, in accordance with the criterion of meaning. Thus, an elder person is capable of entering more and more deeply into the their experiences, understanding them better, recognizing meaning in what was once elusive or even appeared as insignificant. One's own wide-ranging life context, the ability of matching the contrary, understanding paradoxes help re-evaluate befallen events, accept the contradictions and mentally cope with even painful occurrences or times where certain limits were exceeded. This does not mean, however, that this kind of positive development changes are shared by all seniors, they only apply to people aging in the so-called: "normal", that is - non-pathological mode thereby tending to their mental condition. And this is facilitated by the particular lifestyle practiced at the preceding periods during the life span. Moreover, what is found helpful is the physical and mental exercise combined with traits such as openness to new experiences, conscientiousness or extraversion (Byczewska-Konieczny, 2015). Cognitive transformations translate into the preferences in terms of specific goals and forms of activity as well as relationships with the environment along with the attitude to oneself, one's whole life. Temporal reorientation and the appearance of the need for symbolic return to the past, together with the preference for what is known or simply feels safe is a significant development tendency which has influence on tapping into the subject potential in late adulthood. At the same time, the elderly wrestle with the difficulties making decisions, shyness as pensiveness and reflection become the predominant form of mental activity. This kind of activity is driven by the need for getting inner harmony, reconciliation of the individual with the world and oneself, leads to a certain kind of confrontation with the past, summary and the ensuant balance of life experiences. Oftentimes, this kind of activity amounts to completing one's life consisting in settling previously unresolved issues, which occurs with a sense of personal mission or is even perceived as destiny itself. The said theme is reflected in undertaking specific, partly new activities by elder people. In most cases, these are generative activities which are aimed at serving younger members of communities. Also, such activities include charity events, consisting in sharing one's resources, tending to those in need - and finally the development of their interests. In all those instances we deal with the intentional, agentic intentionality based on the will to act underpinned by the need for being in the world as a selfdetermined entity, exerting influence over the surrounding reality in accordance with their own willingness with the sense of obligation and responsibility as well as the desire to feel that, eventually, life does have a meaning.

\section{Creative activity of seniors as an indication of their subjectivity}

A peculiar, one could say, elitist form of subjectpotential realization over the duration of the adulthood is creative activity, including artistic production as well. On the one hand, it is made present with its inherent intentionality of a person, through the need for expression 
of thoughts, visions, feelings or - lastly - one's Self. On the other hand, in the created works present are noticeable - from a psychological perspective - developmental regularities, typical of persons at a particular stage of development, in this case, the elderly people. Therefore, creative activity appears to be both: a way of selfexpression, transgression and self-actualization on one plane and vital source with mental well-being backup, satisfaction and sense of meaning on another - whereas the created works may be somewhat considered to be the mirror of the psychic life of the artist. However, developmental and creative potential per se, along with abilities or the gift itself are not sufficient to draw from, in order for people to give the world pleasure or make them experience creative joy themselves. The will to create and self-determination prove to be indispensable here. To the circle of Polish creators, who worked creatively for the remainder of their life belonged among others, John Paul II, Czesław Miłosz or Stanisław Lem. On the other hand, there were clearly creators who yielded to senescence early on, either due to feelings of impotence (e.g. Juliusz Słowacki) or the feelings of senselessness of their endeavors with respect to the perceived world (e.g. Tadeusz Konwicki). In order for the creative activity of the elderly to thrive, it is important that the they previously develop a proper lifestyle as well as the related attitude to the old age. It emerges that the most favorable attitude is the constructive approach, accompanied by a strong track record, the acceptance of the old age, the upbeat outlook on the future, despite its naturally narrowing perspective, along with the well-disposed attitude towards the world (see: Steuden, 2011). Paradoxically, it is also the defensive attitude that can be conductive to creative activity. This happens when a person was in their element when performing their job at the former stages of life, when the said work activities underpinned it and resulted in creating the source of one's subjective meaning of life. Moreover, with aging creative activity, similarly like any other activity, may serve the defensive function against negative feelings related to advancing changes in the organism such as loss of physical endurance, status or the existential angst, driven by the experience of the certainty of passing and the resultant end of life anticipation. In creatively disposed people, though activity not only deflects attention from unpleasant, gloomy thoughts, giving a sense of contentment, the source of which is the mere fact of being simply active, but it also helps convert thoughts into creative output, too. However, it has to be added that those works do not always emanate joy or optimism.

Both biographies and the works of outstanding senior creators exhibit many peculiar characteristics of their personalities just as they do features typical of the whole generation of elders. Although prominent creators still remain identifiable to their recipients, especially fans, primarily on the basis of their characteristic, unique pieces of art, yet one can see some common features indicative of the general tendencies or developmental regularities Experts in the field of art and these include, among others, Mieczysław Wallis, the author of the book, titled, The late output of grand masters (1975) claims that works created in the autumn years are distinguished in terms of the above average ease of expression visible in the form, the way of employing means of expression (e.g. the language) and they often defy conventions and rules the very same artists used to comply with. As an example, Wallis indicates the creation by Michelangelo who "in Last Judgement went beyond any traditional rules of painting art, similarly to Goethe, who in the second part of Faust did not take into account any respect of space or time" (Wallis, 1975, p. 165). Some critics treat this peculiar extravagance of outstanding artists as an indication of "aspiration towards monumentalism" (op. cit., p. 166). Possibly, however, this is, above all, the already mentioned effect of one's creative ease along with the feeling of independence, or even what is simultaneously occurring - the proof of the cumulated experiences throughout the course of one's life, scrambles of thoughts which are hardly expressible either in language or via means understandable to younger, much less experienced recipients. Many older creators find themselves engaging in themes which had proved important to them earlier on, but were difficult to accomplish due to lack of sufficient means at that time. Goethe who wrote Faust in his twilight years can serve as an example similarly to Michelangelo the creator of the famous Pieta or Beethoven, the composer of Ode to Joy. The tendencies to develop former ideas and putting them into a new shape are probably motivated by the already mentioned elders' need for the return to the past, the spontaneous activation of memories and their exhilarating effect. One can recognize in artists the urge to complete their works, to express experiences, reflections, gained wisdom and the need to share it with others in a somewhat testamentary quintessence. As Claud Monet put it in the following words: „(...) I would not like to die having not said what I needed to say, or at least without having tried to do so." (see: Wallis, p. 175). In this context, Cyprian Kamil Norwid's telling, poetic phrase reminds us that:

\section{Diverse abundance shall disappear and creep away Treasures and strengths shall blow through and the public shall quiver \\ Out of the things of this world only two will last, Only two of them: poetry and charity... and nothing more...}

Michelangelo, openly expressing his fear of death as well as the terror of fragility concerning matter and body he had previously took such great delight in, he was even of the opinion that "it is only a person tormented by senility who can say something really sensible about life's meaning" (see: Przybylski, 1998, p. 31). It is worth noting that Michelangelo found comfort and "rescue" against complete mental anguish in The Risen Christ. This distinguished artist who was already valued in his lifetime, enjoying company of numerous friends, is also - paradoxically an example that loneliness commonly thought to be one of the greatest enemy of the old age does not have to be necessarily experienced as drama. He preferred solitude to 
social meetings. Przybylski cites the following opinion of Michelangelo' biographer (Ascanio Condiviego): “...he preferred to cogitate and maintain a dialogue with himself" (p. 19). Albert Einstein took a similar attitude towards old age. In an interview cited by A. Calaprice and F. Dyson (2014, p. 79) he confessed: "I live in solitude which is most bothering in the younger years, it is a blessing for a mature adult, though". Antonina Gurycka, a particularly appreciated psychologist raises the controversial issue of loneliness in her autobiographical book entitled, You never know (2001). Although the author agrees that in autumn years (yet, not only then, she stresses) loneliness is one of the most challenging human problems, worsened by health, agility-based, and social restrictions, but she points out that what often seems to be neglected is the positive aspect of loneliness she found in her personal experience. She confessed that at a certain moment of her already senior life she felt the "delight of solitude". She writes that solitude may be experienced as a "gift of autumn time" (p. 175). This can happen when a person has grown tired of struggling with life problems and, is at the same time, reflectively-disposed; driven by the need for meditations and "being with oneself". Gurycka offers well-proven suggestions which can come in handy when alleviating the loneliness experience. She recommends "finding some objective of activity in oneself; to love rather than wait on somebody's love returned; to feel the pleasure and chance of possibilities loneliness presents this implies ease as well as finding a partner to talk and experience reveries." (included therein). In any case, this is by no means an easy or effective strategy to use. Undoubtedly, though its implementation is a notable sign of subjectivity. For those who experience serious difficulties coping with loneliness and any tribulations of the old age for that matter, Gurycka simply advises undertaking an activity, attempting to discover or stimulate passion for something and giving oneself the chance to actualize one's self a chance to do something one could not find the time for before, something which got replaced by everyday life of the former "plain being". She writes about the "third incarnation", about finding oneself at the beginning of a new road (p. 147-148). She cites a number of examples of her acquaintances, who although in their senior years, lead a very active life full of joy-giving activities and a sense of meaning, diverting elder people's attention from the kind of things they did not have any influence on - thus pushing unaccepted loneliness away. "An activity - the author of the cited work writes - makes it possible for us not feel like a born loser" (p. 174). Using the convention accepted in this article, one might say that in being active, a man is not only a subject, but he can also have a sense of empowerment. It is worth noting that for Antonina Gurycka, as well as some of the previously mentioned creators, their formed and enhanced religious faith transpired to be instrumental in coping with loneliness thanks to the fact that earlier on, "when it comes to God, everything was there: rebellion, negation, indifference, humility" (p. 178). Obviously, references to Transcendence cannot be considered as a common prescription countering loneliness. However, for many, it proves to be the most effective of all means available. The meaning of Transcendence in human's life, especially the elder one's, is appreciated even by skeptics or atheists themselves. Einstein in a letter to his friend wrote: "there may, however, be something eternal which is far beyond the hand of fate and all human illusions. And such timeless phenomena are closer to elders than youngsters. (...) People like you and I (...) do not grow old no matter how long they live. My point here is, we never cease to be as curious as children are in the face of this grand Mystery we were born into" (see: Calaprice, Dyson, 2014, p. 79). Jan Strelau, another outstanding Polish psychologist, interviewed by Tygodnik Powszechny confessed: "the belief of meeting God and eternal life is the greatest, unparalleled gift a man can be given. And in this sense, I regret departing from faith" (2016, p. 31).

The most important factor, multiplying melancholy or even depression in the elderly at that, apart from the apparent end-of-life perspective and experiencing everyday tribulations caused by lowered vitality as well as loneliness, is the critical glimpse of their past. One could even think that melancholy is an indispensable companion in profound reflection and, by extension, is the characteristic feature of the subjectiveness in an elder person. In this respect, bearing the sign of admonition, is a very telling poem by Czesław Miłosz entitled, Yet another contradiction from the volume At the River Bank (1994, p. 27):

Have I accomplished what I had to do here on earth? I was a visitor at home under the skies Where the rivers flow and crops are made anew What benefit do I gain if called when hardly awake Next time I would look for wisdom sooner

I would not have pretended I could be like others

For this is where evil and affliction come from

Similarly, Zbigniew Herbert in his poem entitled Resume from the volume Rovigo (1995, p. 12) critically writes about his life - in an end-of-life perspective:

\section{I may not have lived - but persevered - unwillingly thrown in at the deep end Into something one can neither have control over nor comprehend \\ like a shadow on the wall, so - this was not a life lived to the fullest (...) \\ I'm lying now in hospital, dying of senescence} I have to struggle with the same old anxiety and torment. Were I to be born again I might be a better man.

In another poem entitled: To Peter Vujicic from the same volume (p. 33), the poet makes confessions, somewhat summing up his life outcome:

...I have made it

One could say I was born with the silver spoon in my mouth 


\section{Explain it to others \\ I have had a wonderful life \\ I have been suffering}

Ryszard Przybylski, Polish literary scholar, in characterizing senescence through the visions appearing in the pieces of work by Michelangelo, T.S. Eliot, Jarosław Iwaszkiewicz and Tadeusz Różewicz confirms - referring to the views held by Nietzsche - that in the face of old age "a man starts to re-evaluate all values" (1998, p. 101). Everything, which previously went unnoticed or was part of repressed consciousness either acquires a new significance or "returns to the original sense". An old person "opens the door of consciousness into an extremely essential, yet at the same time, subdued and uncertain self-knowledge" (p. 121). This spiritual state was mirrored in Tadeusz Różewicz's sad admission adduced by Przybylski: "Although I know everything, I'd rather not know it" (p. 122). Przybylski attributes "sober melancholy" as opposed to "somber melancholy" to Różewicz. Thus, sober melancholy, whose essence also constitutes sadness, has a somewhat "brighter" color, it is based on a more realistic view taken on senescence, it is characterized by, among others, thus avoiding exaggeration, which is displayed in Różewicz's poems via considerable economy of words, focusing on content rather than feelings, the withdrawal from strong and imprecise terms. What is downright striking in the poet's subsequent creative work, is the attention paid to the language precision. In his poem, entitled "Poetic seasonautumn 1966", he confesses: "Of course, over the course of twenty five years I have had various concepts (...) And now (...) I pay heed to but one thing: the Word" (see: Przybylski, p. 123).

Along with the progressive difficulties in terms of spatial imagination and in respect of the narrowing frames of the material world, there increases the spiritual sensitivities in the elderly, - the Transcendent, extramaterial perspective becomes of important also. Maria Dudzik, inter alia, writes about it in her poem entitled Space and time, from the volume entitled Into the light (1998, p. 58).

$$
\begin{aligned}
& \text { my space, which I can walk or drive through, } \\
& \text { - gets narrowed - }
\end{aligned}
$$

associate it with the present tense during the day (...) my vertical reaching is increasing, though and I can see

I want to insistently see

The Eye in the Triangle

On and on

this is my decline

Also, Zbigniew Herbert's poem entitled The prayer of $\mathrm{Mr}$ Cogito - the traveller, from the volume The report from the besieged city (1995, p. 19-21), while being the poet's specific examination of his conscience, it is at the same time the expression of rapture over the world and thanksgiving for the goodness received:
Lord, I thank you for making the world so beautiful and so very diverse and for letting me - in your infinite goodness - be in places

which were the places of my every day desolation (...)

thank you Lord, for making the world so beautiful and so very diverse

and if this is your seduction - then, I am seduced forever and with no chance of forgiveness.

\section{Conclusion}

The provided examples of indications of elder creators' subjectivity can by no means be regarded as representative of the whole senior people population. Those examples only illustrate the specific characteristics of existential situation of an elder human being, which are given voice to in their works and which additionally stay in line with the opinions of the scholars who deal with issues facing aging seniors. Above all, they go to prove that a person can remain creatively active until they reach a ripe old age. This is, undoubtedly, a sign of his subjectivity. In the creators' works of art one can see the attention paid to their experiences and memories form the past as well as a distinct tendency to formulate summarising comments together with analyzing their life outcome. The topic of loneliness, passing and demise is also there. The increased contemplativeness forming main manifestation of inner subjectivity with the simultaneous awareness concerning aging process with the resultant numerous limitations make melancholy the predominant mood found in the output of elder creators.

\section{References}

Byczewska-Konieczny, K. (2015). Rezerwa poznawcza i jej źródta $w$ wieku senioralnym. Niepublikowana praca doktorska. Instytut Psychologii UJ.

Calaprice, A., Dyson, F. (2014). Einstein w cytatach (przeł. M. Krośniak). Warszawa: Wydawnictwo Poltext.

Dudzik, M. (1998). Ku świattu. Kielce: Wydawnictwo „Jedność”.

Erikson, E. (2004). Tożsamość a cykl życia. Poznań: Wydawnictwo Zysk i S-ka.

Gadamer, H.G. (2003). Język i rozumienie. Warszawa: Fundacja Aletheia. Goldberg, E. (2014). Jak umyst rośnie $w$ siłę gdy mózg się starzeje. Warszawa: Wydawnictwo Naukowe PWN.

Gurycka, A. (2001). Nigdy nie wiadomo. Warszawa: Wydawnictwo WIP. Herbert, Z. (1995). Raport z oblężonego Miasta. Wrocław: Wydawnictwo Dolnośląskie.

Herbert, Z. (1995). Rovigo. Wrocław: wydawnictwo Dolnośląskie.

Kant, I. (2001). Uzasadnienie metafizyki moralności. Kęty: Wydawnictwo Antyk.

Miłosz, Cz. (1994). Na Brzegu Rzeki. Kraków: Wydawnictwo Znak.

Prusak, J. (2016). Zwierzę, które się modli. Tygodnik Powszechny, 8(3476), 37.

Przybylski, R. (1998). Baśń zimowa. Esej o starości. Warszawa: Wydawnictwo Sic!

Schnabel, U. (2015). Zmierzyć wiarę. Dlaczego wiara góry przenosi i skąd się bierze. Warszawa: Wydawnictwo Literackie MUZA SA.

Steuden, S. (2011). Psychologia starzenia się i starości. Warszawa: Państwowe Wydawnictwo Naukowe. 
Straś-Romanowska, M. (2010). Od samooceny do poczucia godności. In A. Kolańczyk i B. Wojciszke (red.), Motywacje umystu (s. 127-145). Sopot: Wydawnictwo Smak Słowa.

Straś-Romanowska, M. (2011). Późna dorosłość. In J. Trempała (red.), Psychologia rozwoju człowieka. Warszawa: Wydawnictwo Naukowe PWN (s. 326-349).

Strelau, J. (2016). Dzieło życia i...wystarczy. Tygodnik Powszechny, 13, 30-33

Tillich, P. (1983). Męstwo bycia. Paryż: Editions Du Dialogue.
Trempała, J. (2011). Psychologia rozwoju człowieka. Podręcznik akademicki. Warszawa: Państwowe Wydawnictwo Naukowe.

Trzópek, J. (2013). Na tropach podmiotu. Między filozoficznym a empirycznym ujęciem podmiotowości. Kraków: Wydawnictwo Uniwersytetu Jagiellońskiego.

Wallis, M. (1975). Późna twórczość wielkich artystów. Warszawa: Państwowy Instytut Wydawniczy.

Vetulani, J. (2011). Piękno neurobiologii. Kraków: Wydawnictwo Homini $\mathrm{SC}$. 